\title{
THE REAL PROPERTY MARKET IN THE RUSSIAN FEDERATION IN Q1 2015
}

\author{
G.Zadonsky
}

In January-April 2015, entities of all the patterns of ownership built 295,100 apartments with the total floorspace of $23.4 \mathrm{~m} \mathrm{sq}$. meters which is equal to $128.4 \%$ as compared to the respective period of 2014. In Q1 2015, the average actual cost of building of a sq. meter of housing rose by 1.25\% as compared to Q1 2014 and amounted to $R b$ 39,790. In Q1 2015, the volume of registration of individuals' titles to land plots $(1,358,000$ certificates) increased by $8.23 \%$ as compared to Q1 2014. In January-April 2015, 184426 mortgage housing loans (MHL) for the total sum of $R b 297,819 \mathrm{bn}$ were extended (it is $36.75 \%$ and $39.66 \%$ lower in quantitative and monetary terms, respectively as compared to January-April 2014). In April 2015, the weighted average rate on MHL extended within a month in rubles amounted to $14.05 \%$ against $14.7 \%$ in March.

In January-April 2015, entities of all the patterns of ownership built 295,100 apartments with the total floorspace of $23.4 \mathrm{~m} \mathrm{sq}$. meters which was equal to $128.4 \%$ as compared to the respective period of 2014, including 59,700 apartments in April with the floospace of $4.9 \mathrm{~m}$ sq meters or $115.2 \%$ against April 2014 as regards the volume of floorspace. Individual developers built $11.8 \mathrm{~m}$ sq. meters of housing or $50.46 \%$ of the total volume of housing commissioned in JanuaryApril 2015.

According to the data of the Rosstat, in Q1 2015 entities of all the patterns of ownership built 235,400 apartments with the total floorspace of $18.5 \mathrm{~m}$ sq. meters which was equal to $132.8 \%$ as compared to the respective period of the previous year. Individual developers built $9.4 \mathrm{~m}$ sq. meters of housing or $51.04 \%$ of the total volume of housing commissioned in Q1 2015 (Fig. 1).

In Q1 2015, the average actual price of building of a sq. meter of housing amounted to Rb 39,790 (Fig. 2), having increased by $1.25 \%$ as compared to Q1 2014 ( $R b$ 39,290). In Q1 2015, the average price of a sq. meter of housing on the primary real-estate market ( $\mathrm{Rb} 52,600$ ) rose by $5.32 \%$ as compared to Q1 2014 remaining below the average price of a sq. meter of housing on the secondary market ( $\mathrm{Rb} 58,730$ ) which price also appreciated as compared to Q1 2014. It is to be noted that in Q1 2015 the correlation between the price of a sq. meter of housing on the primary market as percentage of the cost of building of a sq. meter of housing fell by 5.11 p.p. as compared to Q1 2014 and amounted to $132.2 \%$ (Fig. 2).

In Q1 2015, the highest cost of building which exceeds by 1.5 times or more the average nationwide level was observed in the Sakhalin Region ( $R b$ 62,636) and Moscow (Rb 57,980). In 60 constituent entities of the Russian Federation that cost was below the national average with the lowest one registered in the

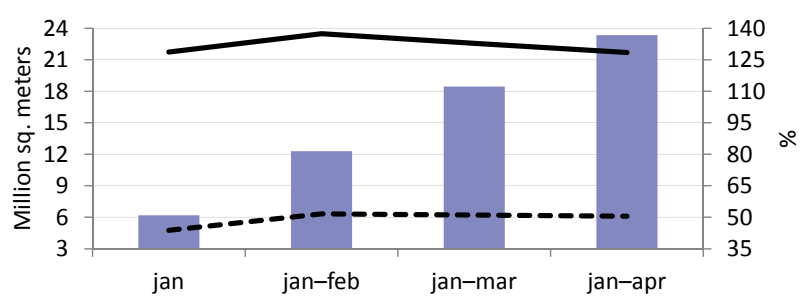

Housing commission from the beginning of the year, million sq. meters

Housing commissioned as \% of the respective period of the previous year

- - Housing commissioned by individual developers as \% of the total volume of housing in the period from the beginning of the year

Source: on the basis of the data of the Rosstat.

Fig. 1. Dynamics of commissioning of housing in 2015

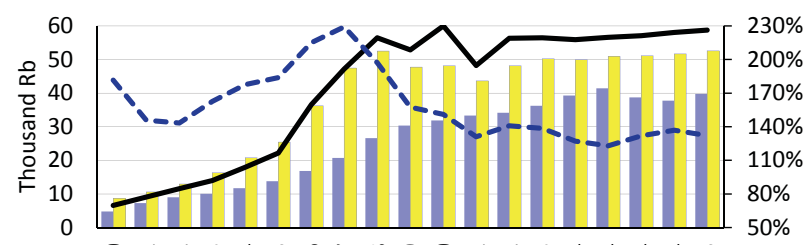

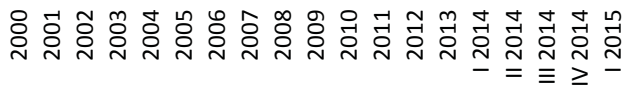

The average actual price of building of a sq. meter of housing*, thousand $\mathrm{Rb}$

The average price of a sq. meter of housing on the primary market**, thousand $\mathrm{Rb}$

-The average price of a sq. meter of housing on the secondary marker**, thousand $\mathrm{Rb}$

- - The average price of a sq. meter of housing on the primary market as \% of the average actual price of building of a sq. meter of housing

* average actual cost of building of a sq. meter of housing of detached dwelling houses (all the apartments) without extensions, overstory and in-built facilities in the Russian Federation (without those built by households at their own account and by means of borrowed funds);

** all the apartments.

Source: on the basis of the data of the Rosstat.

Fig. 2. Dynamics of building of a sq. meter of housing and prices of a sq. meter of housing on the primary and secondary markets of the Russian Federation 
Orel Region ( $\mathrm{Rb} 21,438)$, the Republic of Dagestan ( $R b$ $22,282$ ) and the Stavropol Territory ( $R b 24,426)$.

According to the Rosreestr's data, in Q1 2015 the number of individuals' registered titles to housing $(2,238,412$ certificates) increased by $8.32 \%$ as compared to Q1 2014 (Fig. 3), while the number of legal entities' registered titles to housing $(47,781$ registration certificates) increased within the same period by $2.67 \%$.

According to the data of the Rosreestr, in Q1 2015 the volume of registration of individuals' titles to land $(1,357,913$ certificates) increased by $8.23 \%$ as compared to Q1 2014. In Q1 2015, the volume of registration of real property units in accordance with the simplified procedure - the so-called "summer cottage" amnesty - amounted to 268,189 certificates which is 63.47\% higher than in Q1 2014. It is to be noted that in the above value the number of titles to land plots registered in accordance with the simplified procedure amounted to 96851 certificates which is $38.51 \%$ lower than in Q1 2014. Registration of individuals' titles to land plots in accordance with the simplified procedure as percentage of registration of individuals' titles to land plots (total) amounted to $7.13 \%$ in Q1 2015 against 5.57\% in Q I 2014 (Fig. 4).

The number of registered titles of legal entities to land plots fell by $7.75 \%$, having amounted to 52323 certificates in Q1 2015. In Q1 2015, leasehold of land plots by individuals ( 18735 certificates) increased by $15.38 \%$ as compared to Q1 2014 , while that by legal entities (4343 certificates) fell within the same period by $74.48 \%$.

As compared to Q1 2014, in Q1 2015 the number of land plot mortgages for individuals $(101,752$ certificates) fell by $30.72 \%$, while that for legal entities $(23,653$ certificates), by $24.27 \%$.

In Q1 2015, the number of individuals' housing mortgages fell by $15.51 \%$ ( 244,621 certificates) as compared to Q1 2014. It is to be noted that in Q1 2015 the number of mortgages of housing owned by individuals and purchased (built) either by means of credit resources or a purpose loan $(184,893$ mortgages) fell by $18.22 \%$ as compared to Q1 2014 (Fig. 5).

According to the data of the Central Bank of the Russian Federation, in January-April 2015 Rb 304.53bn worth of 189,549 housing loans were extended, including 184,426 mortgage housing loans for Rb $297.82 \mathrm{bn}$ which is $36.75 \%$ and $39.66 \%$ lower than MHL extended in January-April 2015 in quantitative and monetary terms, respectively.

In April 2015, 49,267 mortgage housing loans in rubles for $\mathrm{Rb} 80.65 \mathrm{bn}$ were extended which was $47.40 \%$ and $49.75 \%$ lower in quantitative and monetary terms, respectively, than in April 2015 (Fig. 6); mortgage housing loans in foreign currency

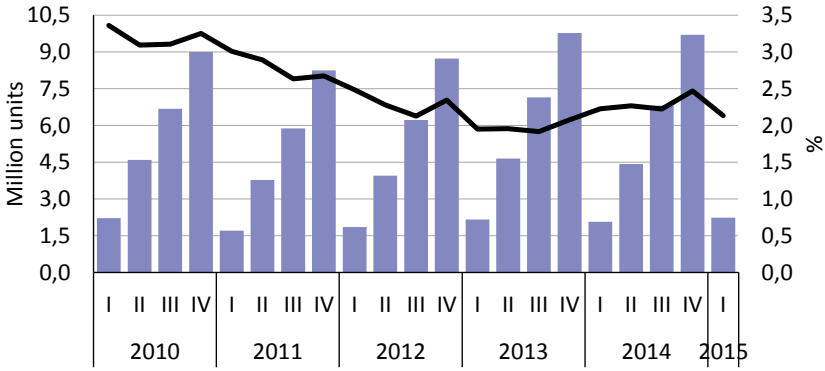

The volume of registration of individuals' titles to real property, million units

-The volume of registration of legal entities' titles to legal property as \% of the volume of registration of individuals' titles

Source: on the basis of the data of the Rosreestr.

Fig. 3. Dynamics of state registration of titles to housing

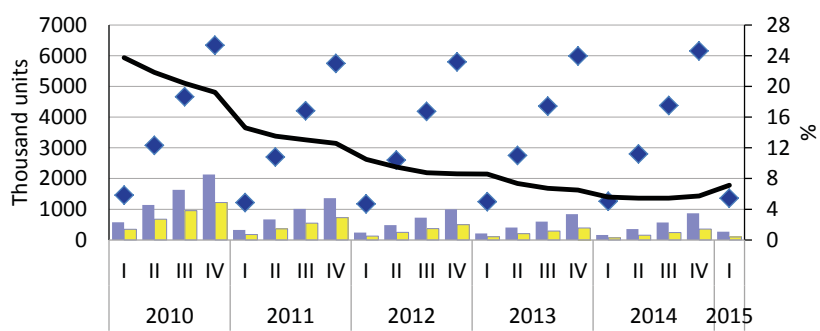

Registration of individuals' titles to some real property units in accordance with the simplified procedure, thousand units

Registration of individuals' titles to land plots in accordance with the simplified procedure, thousand units

- Registration of individuals' titles to land plots (total), thousand units

- Registration of individuals' titles to land plots in accordance with the simplified procedure as \% of registration of individuals' titles to land plots (total)

Source: on the basis of the data of the Rosreestr.

Fig. 4. Dynamics of state registration of individuals' titles to land plots

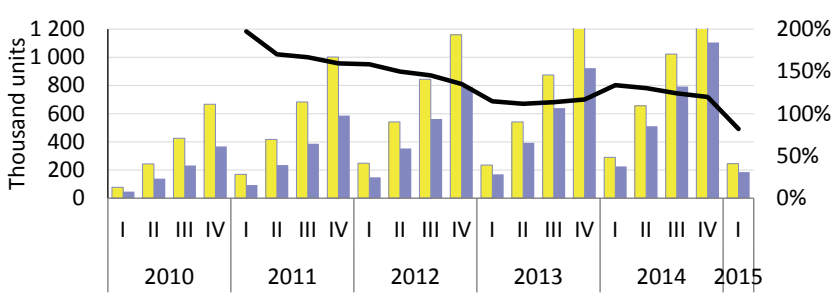

$\square$ Individuals' mortgages (total), thousand units

Mortgage of housing purchased (built) by individuals by means of credit resources or a purpose loan, thousand units

-Mortgage of housing purchased (built) by individuals by means of credit resources or a purpose loan as $\%$ of the respective period of the previous year

Source: on the basis of the data of the Rosreestr.

Fig. 5. Dynamics of state registration of housing mortgages

were extended for $\mathrm{Rb} 0.21 \mathrm{bn}$ which is $79.37 \%$ lower than in April 2014 (Fig. 7). In April 2015, the outstanding debt on $\mathrm{MHL}$ in rubles rose by $23.37 \%$ to $\mathrm{Rb}$ 3.45 trillion, while that on loans in foreign currency, by $3.85 \%$ to $R b 114.54 \mathrm{bn}$. 


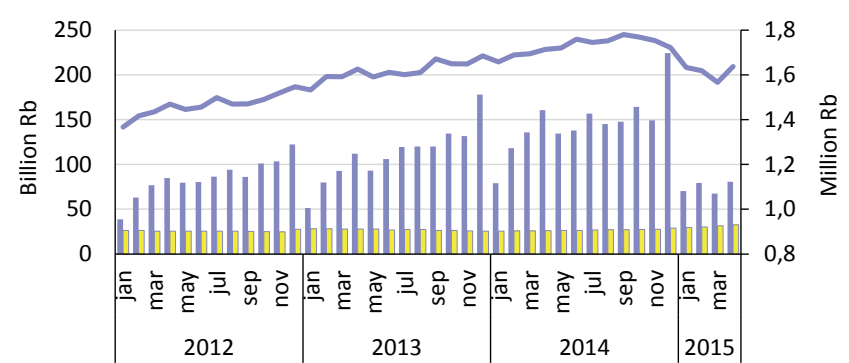

The volume of the extended MHL, left-hand axis, billion Rb

$\square$ The overdue payments on $\mathrm{MHL}$, left-hand axis, billion $\mathrm{Rb}$

-The average value of $\mathrm{MHL}$ within a month, right-hand axis, million $\mathrm{Rb}$

Source: on the basis of the data of the Central Bank of the Russian Federation.

Fig. 6. Dynamics of $\mathrm{MHL}$ in rubles within a month

From April 2014, the average monthly value of MHL in rubles fell by $4.46 \%$ and in April 2015 amounted to $\mathrm{Rb}$ $1,637 \mathrm{~m}$ (Fig. 6). The share of MHL in foreign currency is steadily decreasing. In April 2015, only 4 loans were extended. In April 2015, the average monthly value of $\mathrm{MHL}$ in foreign currency amounted to $\mathrm{Rb} 52.5 \mathrm{~m}$ which is 4.02 times higher than in April 2014 (Fig. 7).

As of 1 May 2015, the overdue debt on MHL (Rb 32,417 bn on loans in rubles (Fig. 6) and Rb 16,821bn on loans in foreign currency (Fig. 7)) amounted to $\mathrm{Rb}$ $49.24 \mathrm{bn}$ which is $20.42 \%$ more than that as of 1 May 2014.

According to the data of the Central Bank of the Russian Federation, as of 1 May 2015 the debt on defaulted MHL (with a period of delay of over 180 days) amounted to $\mathrm{Rb} 64.13 \mathrm{bn}$ and as percentage of the total debt, to $1.80 \%$, which is equal to the index of 1 May 2014 (Table 1). As of 1 May 2015, from 1 April 2014 the share of the debt on MHL without overdue payments increased by 0.85 p.p. and amounted to 94.44\% (Table 1).

In April 2015, the weighted average rate on $\mathrm{MHL}$ extended within a month in rubles amounted to $14.05 \%$ against $14.7 \%$ in March 2015 (Fig. 8). The

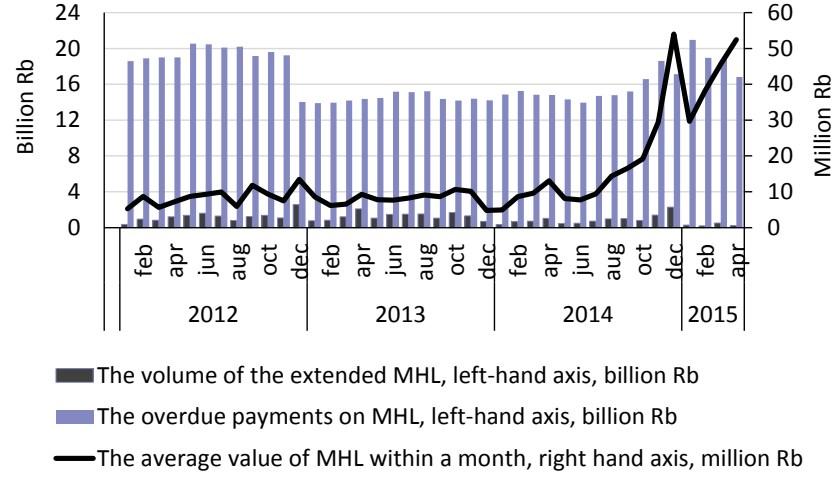

Source: on the basis of the data of the Central Bank of the Russian Federation.

Fig. 7. Dynamics of MHL lending in foreign currency within a month

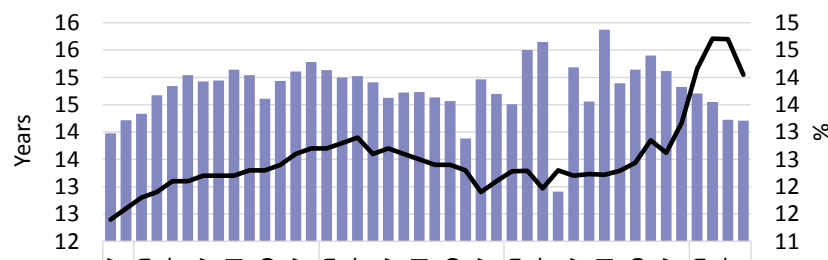

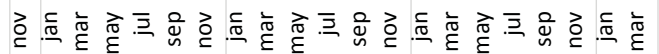

\begin{tabular}{|l|l|l|l|l|}
2011 & 2012 & 2013 & 2014 & 2015 \\
\hline
\end{tabular}

The weighted average period of lending as regards MHL extended within a month, years

-The weighted average rate on MHL extended within a month, \%

Source: on the basis of the data of the Central Bank of the Russian Federation.

Fig. 8. The weighted average periods and rates on $\mathrm{MHL}$ in rubles extended within a month

weighted average rate on housing loans in rubles extended within a month amounted to $14.73 \%$ and $14.46 \%$ in March and April, respectively. In April 2015, the weighted average rate on $\mathrm{HL}$ and $\mathrm{MHL}$ extended from the beginning of the year rose to $12.01 \%$ and $11.57 \%$ as regards $\mathrm{HL}$ and $\mathrm{MHL}$, respectively (Fig. 8).

In April 2015, the weighted average periods as regards loans in rubles extended within a month

GROUPING OF THE DEBT ON MORTGAGE HOUSING LOANS BY THE PERIOD OF DELAY IN PAYMENTS

\begin{tabular}{|c|c|c|c|c|c|c|c|c|c|}
\hline \multirow{4}{*}{2014} & \multirow{4}{*}{$\begin{array}{l}\text { Debt on } \\
\text { MHL } \\
\text { Million Rb }\end{array}$} & \multicolumn{8}{|c|}{ including } \\
\hline & & \multirow{2}{*}{\multicolumn{2}{|c|}{$\begin{array}{l}\text { Without overdue } \\
\text { payments }\end{array}$}} & \multicolumn{6}{|c|}{ With overdue payments } \\
\hline & & & & \multicolumn{2}{|c|}{ From 1 day till 90 days } & \multicolumn{2}{|c|}{$\begin{array}{l}\text { From } 91 \text { days } \\
\text { till } 180 \text { days }\end{array}$} & \multicolumn{2}{|c|}{ over 180 days } \\
\hline & & Million $\mathrm{Rb}$ & $\% *$ & Million $\mathrm{Rb}$ & $\% *$ & Million $\mathrm{Rb}$ & $\% *$ & Million $\mathrm{Rb}$ & $\% *$ \\
\hline 01 Jan & 3528379 & 3369955 & 95.51 & 83270 & 2.36 & 13055 & 0.37 & 62099 & 1.76 \\
\hline $01 \mathrm{Feb}$ & 3566635 & 3367617 & 94.42 & 115559 & 3.24 & 15693 & 0.44 & 67766 & 1.90 \\
\hline $01 \mathrm{Mar}$ & 3564409 & 3379773 & 94.82 & 102298 & 2.87 & 16396 & 0.46 & 65942 & 1.85 \\
\hline $01 \mathrm{Apr}$ & 3559007 & 3358990 & 94.38 & 111753 & 3.14 & 23134 & 0.65 & 65130 & 1.83 \\
\hline 01 May & 3562707 & 3364620 & 94.44 & 111513 & 3.13 & 22445 & 0.63 & 64129 & 1.80 \\
\hline
\end{tabular}

* of the total sum of the debt.

Source: the data of the Central Bank of the Russian Federation. 
decreased as compared March 2015 as follows: by $0.12 \%$ to 14.21 years (Fig. 8 ) and $0.65 \%$ to 14.0 years as regards MHL and HL, respectively. In April 2015, the average period of lending as regards loans in foreign currency extended from the beginning of the year showed a decrease as compared to the period of lending in 2014 , too: by $74.03 \%$ to 3.17 years and $74.71 \%$ to 2.7 years, respectively.

In January-May 2015, eight originators, including OAO AHML carried out $\mathrm{Rb} 40.04$ bn worth of deals on securitization of mortgage housing loans.

Within the frameworks of restructuring program, the OAO AHML is planning to support borrowers from among socially priority categories of individuals in accordance with Resolution No.373 of 20 April 2015 of the Government of the Russian Federation. The AHML has approved all the required documents for implementation of the program and placed at its Internet site the detailed information for creditors (lenders) on the procedure for payment of compensation with the preliminary forms of documents required for that purpose enclosed.

According to the Order No. 108 of 28 April 2015 of the Ministry of Finance of the Russian Federation, for OAO AHML a limit has been established on issuing (purchasing) of mortgage loans within the frameworks of the program of subsidizing of interest rates on mortgage loans for purchasing of primary market housing (mortgage with a state support) in the amount of $\mathrm{Rb}$ $32.28 \mathrm{bn}$ (instead of the requested $\mathrm{Rb} 45 \mathrm{bn}$ ). 